\title{
Training teacher-tutors for developing giftedness in children during research
}

\author{
Tatiana Ivanovna Zinovyeva ${ }^{1 *}$, Zhanna Viktorovna Afanasyeva ${ }^{1}$, Antonina Vladimirovna \\ Bogdanova $^{1}$, and Evgeniy Nikolaevich Leonovich ${ }^{1}$ \\ ${ }^{1}$ Moscow City University, Teaching Methods Department, Institute of Pedagogy and Psychology of \\ Education, Moscow, Russia
}

\begin{abstract}
The article deals with the issues of teacher training in the higher education system. The purpose of the study is to justify the possibility of forming a pedagogue's readiness for tutor support of students' research in the context of developing giftedness in children. The prerequisites for the study are the challenges of the rapidly changing society and the resulting focus of the education policy on nurturing professionals who are competitive in the labor market, increased interest of researchers and organizers of the higher education system in the search for ways to increase the training quality of specialists in every area of social life including the training of specialists in pedagogy. Scholarly achievements in the development of a teacher's professionalism, tutor support in the education process, teaching research, and promotion of giftedness in children are also key factors in the study. The main research method is the method of theoretical analysis of scientific pedagogical and psychological-pedagogical literature. The authors have selected and explored a substantial set of sources in Russian and English published predominantly over the last five years in science-driven databases such as the Russian Science Citation Index, Web of Science, Scopus, and other peer-reviewed outlets. Results and novelty: the context of the recent developments in pedagogical science in the field of training professionals is adequate to the trends and goals of modern education - the inclusion of student teachers in the actual practice of tutor support of students, the organization of teaching research to schoolchildren, and the development of giftedness in children. The solution to these problems is ensured by streamlining the educational process at the university based on a universal model for developing the teacher's professionalism, through the implementation of the reflexive and activity-based approach.
\end{abstract}

Keywords: teacher's professionalism, tutor support, research, giftedness in children.

\section{Introduction}

The modern global community is experiencing a period of accelerated development of technologies that give rise to rapidly changing society processes: technological (digitalization, robotization); techno-social (globalization, greening), social (transformation

\footnotetext{
*Corresponding author: zinovievat@mgpu.ru
} 
of the labor market, the formation of a network society). The growing pace of unpredictable changes creates uncertainty for the future society and explains the demand for universal competencies [1-3].

Social trends are taken into account which is reflected in educational policy: the formation of the personality of a professional who has a high intellectual and creative potential, who can integrate into the world of high technologies, navigate information flows, be competitive is set as a priority task [4-6].

An illustration of the response of the education system to the challenges of society is its digital renewal. In 2018, researchers noted "a positive trend towards digital innovation among teachers" [7]. In 2020, the results of an online survey conducted among teachers working remotely during the pandemic showed that the system of Moscow education was updated in terms of its digitalization; the personnel was trained and competent in the field of digital education; teachers had a positive experience of using ready-made digital educational resources and could develop such resources [8].

The growing interest of researchers in the problem of teacher training in the context of society's needs is obvious [5].

\section{Methods}

The leading research method is the method of theoretical analysis which is used to compile a review of pedagogical studies to determine the scientific foundations of the problem of forming teachers' professional readiness for tutor support for the students' research in the context of developing giftedness in children. A substantial set of scientific sources in Russian and English was analyzed, published mainly in the past five years in science-driven databases such as the Russian Science Citation Index (RSCI), Web of Science, Scopus, and other peerreviewed outlets, including those with DOIs.

\section{Results}

Solving the problem of developing the teacher's professionalism is a priority for pedagogical science. The prerequisites for solving the problem are the development of a modern interpretation of the concept of "teacher's professionalism"; creation of a universal theoretical model for the development of teacher's professionalism based on the integration of personological and professiographic approaches [4].

Development of the teacher's professionalism is ensured by organizing the educational process in a particular way - using the reflexive and activity-based approach, within the framework of practice-oriented (under the teacher's guidance, on the basis of a school, in interaction with children) teaching students the foundations of tutor support of research in the context of developing giftedness in children.

The content of the practice-oriented course is made up of A.I. Savenkov's ideas - a conceptual model for the development of giftedness in children, a methodology for research training, and technology for tutor support for research activities.

\section{Discussion}

Studying the problem of preparing a teacher to support the students' research in the context of developing giftedness in children required an analysis of the concepts: teacher's professionalism, tutor support, research, and giftedness in children.

The analysis of academic literature has shown that the category of professionalism is traditionally considered by scholars (A.K. Markova, V.A. Sitarov, V.A. Slastenin, D.J.C. 
Andrews, G. Richmond, A.A. Ifanti, V.S. Fotopoulou, H.H. Gaziel, etc.) as a set of professional competencies and personal qualities of a person that allow one to solve complex professional tasks in different conditions $[1,4,9]$.

According to the modern researcher A.S. Lvova, the teacher's professionalism is an integral personal phenomenon, the highest result of professional development, providing a high level of solving professional problems and the success of the activities performed [4].

The problem of developing professionalism in a future teacher is traditionally presented in the works of researchers (B.G. Ananev, E.A. Levanova, A.K. Markova, etc.) in the context of the task of creating a theoretical model. We share A.S. Lvova's views, according to which a universal theoretical model of the teacher's professionalism should be based on integrating fundamentally different approaches: a personological approach that stems from the principles of personality analysis and determines the creation of a model in the direction "from personality to profession"; professiographic, built on the theory of activity and determining the creation of a model along the path "from profession to personality" [4].

Researchers (Zh.V. Afanaseva, A.V. Bogdanova, V.A. Krivova, A.S. Lvova, L.Yu. Osipenko, A.I. Savenkov, P.V. Smirnova) consider the reliance on the activity-based approach in teaching as a condition for introducing a theoretical model of developing teacher's professionalism into the educational process and a version of this approach $-\mathrm{a}$ reflexive and activity-based approach.

The activity-based approach is seen as a specially organized process in which the priority is given to the maximum degree of independent cognitive activity [10-12].

In terms of the formation of the teacher's professionalism, the priority is the reflexive and activity-based approach, the implementation of which, first, involves the inclusion of students in pedagogical work, within the framework of which basic labor functions are mastered in interaction with the university teacher and students; second, brings the student closer to solving professional problems; third, creates opportunities for the student to comprehend the degree and the reasons for the successful/unsuccessful performance of the teacher's work $[11,13,14]$.

The implementation of these approaches in the practice of training a professional teacher actualizes the idea of tutoring at the level of higher and general education - ensures that students master tutor support for the individual educational paths of students ( $\mathrm{Zh} . \mathrm{V}$. Afanaseva, A.V. Bogdanova, V.A. Krivova, A.S. Lvova, A.I. Savenkov, P.V. Smirnova and others).

There are academic descriptions of models of tutoring support for students implemented in Russian [15] and foreign [16, 17] institutions; the technologies of tutor support are defined $[18,19]$. Particularly interesting are models of tutor support for research $[20,21]$; development of giftedness in children [22-25]; tutor support for a gifted child in the context of interaction between general and professional education [26]. The advantages of tutor support models are identified: the possibility of using tutor support for students of different categories, at different levels of training; the ability to choose any activity as the subject of interaction between the tutor and the students; productivity in the development of giftedness in children; applicability in the practice of teaching tutor support of research to students [26, 27].

We choose the models proposed by A.I. Savenkov and supported by many scholars (T.A. Egorova, A.V. Leontovich, A.S. Obukhov). Following A.I. Savenkov, we view the category of giftedness in children as "the intellectual and creative potential of each child, since in relation to each child we can talk about a certain degree of development of this potential, it can be argued that, under certain conditions, children with different levels of giftedness can reach the highest levels of success" [22]; we interpret research behavior as "an efficient tool that allows one to transform the process of personality development into the process of selfdevelopment" [20]. 
To justify the possibility of developing the teacher's professionalism, there must be publications based on the results of empirical studies of the problem. Let us note the description of the study devoted to teaching students the tutor support of the schoolchildren's research in the context of developing giftedness in children. The study was conducted at the University School of Moscow State Pedagogical University for several years (2014-2020) by teachers of the Institute of Pedagogy and Psychology of the Moscow State Pedagogical University (Zh.V. Afanaseva, A.V. Bogdanova, V.A. Krivova, Yu.A. Serebrennikova, P.V. Smirnova) under the guidance of A.I. Savenkov, the author of the methodology used for teaching research to schoolchildren $[4,14,28]$ According to the researchers' concept, the implementation of the reflexive and activity-based approach as a special organization of student learning consisted in including students in actual work with younger schoolchildren, during which future teachers, under the guidance of university teachers, mastered basic labor functions in practice, relying on the reflection of their own actions. The features of the implementation of the reflexive and activity-based approach were the introduction of training sessions to develop students' research abilities; students' tutor support for research by schoolchildren; mastering a practical course on the management of children's research [4, $14,28]$.

Based on the results of extensive research - a prolonged (during 2014-2020) observation of students' work on tutor support for schoolchildren's research, conversations with participants in the experiment at different stages, the experimenters state a positive trend in motivating the professional activity of future teachers. There are qualitative changes that have occurred in (and due to) the process of the students' tutor support of the research of schoolchildren: the prevalence (74\%) of broad social motives; strengthening the motive of the content of the training as a preferred motive for professional motivation [14]. The increase in indicators of professional motivation, the manifestation of professionalism in activities is evidence that the practice-oriented organization of the educational process at the university is an efficient factor in the development of the teacher's professionalism [4, 29].

\section{Conclusion}

The condition for training a teacher-tutor to support the research of schoolchildren in the context of developing giftedness in children is the formation of the educational process based on the model of developing the teacher's professionalism.

We consider the professionalism of a teacher-tutor in the field of supporting research activities of students in the context of the developing giftedness in children as an integral personal phenomenon, the highest result of professional development, resulting in a high level of solving professional problems. We interpret the category "teacher's professionalism" from the standpoint of the principle of orientation towards the ideal - as the highest value, the superlative degree of the concept of a teacher.

\section{References}

1. D.J.C. Andrews, G. Richmond, Journal of Teacher Education, 70(5), 408-409 (2019). https://doi.org/10.1177/0022487119875098.

2. Ya.I. Kuzminov, P. Sorokin, I. Frumin, Forsait, 13(2), 19-41 (2019)

3. I.M. Remorenko, Gosudarstvenno-obshchestvennye mekhanizmy regulirovaniya obrazovaniya [State and public mechanism of regulating education] (Pero, Moscow, 2017)

4. A.S. Lvova, Razvitie professionalizma pedagoga v usloviyakh sistemno-modulnoi organizatsii obrazovatelnogo protsessa v magistrature [Development of the 
pedagogue's professionalism in the context of the systemic-modular organization of the education process in the Master's program]. Abstract of Dissertation by the Doctor of Pedagogical Sciences: 13.00.08 (Moscow City University, Moscow, 2020)

5. A.S. Lvova, M.V. Voropaev, S.I. Karpova, T.I. Zinovyeva, E.K. Yanakieva, SHS Web of Conferences, 79, 02016 (2020). https://doi.org/10.1051/shsconf/20207902016

6. A.I. Savenkov, O.A. Lyubchenko, S.G. Vorovshchikov, A.S. Lvova, SHS Web of Conferences, 79, 02023 (2020). https://doi.org/10.1051/shsconf/20207902023

7. T.I. Zinoveva, Zh.V. Afanaseva, A.V. Bogdanova, Nizhny Novgorod Education, 3, 121-127 (2018)

8. T. Zinovyeva, Zh. Afanasyeva, A. Bogdanova, E. Leonovich, SHS Web of Conferences, 79, 01020 (2020). https://doi.org/10.1051/shsconf/20207901020.

9. A.A. Ifanti, V.S. Fotopoulou, H.H. Gaziel, Research in Comparative and International Education, 12(4), 486-496 (2017). https://doi.org/10.1177/1745499917740653.

10. O.S. Korneva, Deyatelnostnyi podkhod kak osnova formirovaniya professionalnoi kompetentnosti ekonomistov [Activity-based approach as the foundation for forming professional competence in economists], in Proceedings of the 5th International scientific conference "Theory and practice of education in the modern world", July 2014, Saint Petersburg, Russia, 234-236 (2014)

11. E.A. Levanova, Sovremennye Problemy Nauki i Obrazovaniya [Modern Problems of Science and Education], 3 (2015). Accessed on: December 15, 2020. [Online]. Available: https://science-education.ru/ru/article/view?id=17369

12. L.G. Pak, Yu.P. Yablonskikh, Sovremennye Problemy Nauki i Obrazovaniya [Modern Problems of Science and Education], 6 (2015). Accessed on: December 15, 2020. [Online]. Available: https://science-education.ru/ru/article/view?id=21556

13. V.M. Dyukov, G.S. Pyankova, Sovremennye Naukoemkie Tekhnologii [Modern High Technologies], 10, 103-107 (2010)

14. A.I. Savenkov, Zh.V. Afanaseva, Vestnik Moskovskogo Gorodskogo Pedagogicheskogo Universiteta. Series: Pedagogika i psikhologiya [Bulletin of the Moscow City Pedagogical University. Pedagogy and psychology], 1(39), 8-18 (2017)

15. S.L. Fomenko, Pedagogicheskoe Obrazovanie v Rossii [Pedagogical Education in Russia], 3, 102-107 (2017)

16. O.S. Butenko, V.S. Butenko, Sovremennye Problemy Nauki i Obrazovaniya [Modern Problems of Science and Education], 6 (2015). Accessed on: Descember 15, 2020. [Online]. Available: http://www.science-education.ru/ru/article/view?id=23057

17. L.A. Lopez-Agudo, O.D. Marcenaro-Gutierrez, J.A. Molina-Marfil, Studies in Educational Evaluation, 66 (2020). https://doi.org/10.1016/j.stueduc.2020.100903.

18. V.S. Zaitsev, Tekhnologii tyutorskogo soprovozhdeniya obucheniya studentov: metodicheskoe posobie [Technologies of tutor support for student education: methodological guidelines] (Biblioteka A. Millera, Chelyabinsk, 2018)

19. I.G. Dyakov, O.S. Shcherbinina, Yaroslavskii Pedagogicheskii Vestnik [Yaroslavl Pedagogical Bulletin], 1(106), 23-29 (2019)

20. A.I. Savenkov, Pedagogika. Issledovatelskii podkhod [Pedagogy. The research-based approach]. Part 1 (Izdatelstvo Yurait, Moscow, 2020)

21. M. Haaker, B. Morgan-Brett, SAGE Open, 7(2) (2017). https://doi.org/10.1177/2158244017701800

22. A.I. Savenkov, Psikhologiya detskoi odarennosti [The psychology of giftedness in children] (Yurait, Moscow, 2019) 
23. A. Heyder, S. Bergold, R. Steinmayr, Psychology Learning \& Teaching, 17(1), 27-44 (2018). https://doi.org/10.1177/1475725717725493.

24. A.M. Novak, K.D. Lewis, C.L. Weber, Gifted Child Today, 43(3), 169-183 (2020). https://doi.org/10.1177/1076217520915743.

25. S. Miedijensky, Gifted Education International, 34(3), 222-244 (2018). https://doi.org/10.1177/0261429417754204.

26. A.L. Pikina, Yaroslavskii Pedagogicheskii Vestnik [Yaroslavl Pedagogical Bulletin], II(4), 111-116 (2013)

27. K.J. McFarlane, Active Learning in Higher Education, 17(1), 77-88 (2016). https://doi.org/10.1177/1469787415616720.

28. A.I. Savenkov, Zh.V. Afanaseva, A.V. Bogdanova, V.A. Krivova, Yu.A. Serebrennikova, Nachalnaya Shkola [Primary School], 9, 70-75 (2016)

29. A.I. Savenkov, A.S. Lvova, O.A. Lyubchenko, L.E. Osipenko, Bulletin of the Moscow City Pedagogical University. Series: Pedagogy and psychology, 2(36), 54-61 (2016) 